\title{
Indonesian Trade Deficit with China: Background and Grey Forecasting
}

\author{
Cliford Septian Candra ${ }^{1,} \mid$ Jason Adrian ${ }^{1}$ Varren Christian $\operatorname{Lim}^{1}$ \\ ${ }^{1}$ Binjiang College of Nanjing University of Information Science and Technology, Wuxi, China \\ *Corresponding author: clifordseptianc@gmail.com
}

Received 30 May 2021; Revised 19 June 2021; Accepted 20 June 2021

\begin{abstract}
Indonesia's trade balance with China has remained negative since 2010. The current study forecasts Indonesia's trade deficit with China for five years using the Even Grey Forecasting model EGM $(1,1, \alpha, \theta)$. The sample was conducted by collecting the data of traded deficits for the past ten years. Data were collected from the official websites of Indonesia's Central Bureau of Statistics of (BPS), Ministry of Trade, among others. By building upon the literature, the study argues that trade deficits might have occurred from internal and external factors, such as the lack of infrastructure, the depreciation of the Rupiah (Indonesian currency) against the U.S. dollar, and the ASEAN-China Free Trade Agreement. Comparative analysis with Linear Regression (LR), Exponential Regression (ER), and Exponential Triple Smoothing (ETS) revealed the superiority of the grey forecasting model for trade deficit prediction. The study found that the trade deficit was minimum during the COVID-19 pandemic. It also showed an increasing trade deficit in the post-COVID period. The study concludes with some recommendations for Indonesia to minimize the trade deficit.
\end{abstract}

Keywords: Import; export; trade deficit; east Asia; grey forecasting

\section{Introduction}

The economic condition of a nation, especially in terms of international trade, can be seen by looking at the country's trade balance. The trade balance is one of the instruments in the balance of payments that displays a country's exports and imports (Salvatore, 2011). Existing trade balance statistics will disclose not only the status but also the output of a country's exports and imports. The trade balance can have several conditions. The first condition is that of surplus. If the number of exports exceeds the amounts of imports, the trade balance is said to be in surplus. A country's trade balance is said to be in surplus when the number of imports exceeds the number of exports (Mankiw \& Taylor, 2020).

Deficit trade balance pressures are commonly used as a measure of a country's low economic health. However, a trade deficit doesn't necessarily represent poor economic health. The ability to determine whether the deficit trade balance condition is poor or favorable is heavily dependent on domestic and international economic conditions (Nabila, 2017). However, if the trade balance deficit conditions persist, this should be taken into account because it can imply weak economic conditions, especially in terms of export results. 
China's economy is resilient to disruptions, and its performance during the COVID-19 pandemic has just confirmed the fact (Javed et al., 2021), and thus trade relations with China are highly valued in many nations, particularly in developing countries. China is one of the important trading partners of Indonesia (Sugiartiningsih, 2020). Between 1999 to 2007, Indonesia was excessively surplus with China, and Indonesia only experienced a deficit with China in 2008 (Adam \& Negara, 2010). As China's economic contribution also accounts for one-third of the world's economic growth, China is a significant trading partner (IMND, 2019). Thus, all world trade, including Indonesia, will be affected if China faces a crisis. The story of China's economic slowdown would likely affect commodity demand and a range of consumer goods. Slowing economic activity would reduce import demand. That means that the share of exports in growth will also decrease so that economic growth in Indonesia will also affect its export output if exports worsen.

A matter of concern that prompted the current study was that Indonesia's trade balance with China has remained negative since the last decade. This shortfall does not guarantee that the Indonesian economy is in trouble or that its export output is poor. However, this idea must be considered and looked after since a trade imbalance may be an indication of other issues in a country's domestic economy or at an international economic level that impacts the state of a country's trade balance (Ginting, 2017).

The rest of the study is organized as follows: The second section reviews literature, the third section presents the research methodology, the fourth section involves data and results, and the fifth section presents the conclusion and recommendations.

\section{Literature Review}

\subsection{Indonesia and its international trade}

The Indonesian economy has gone through ups and downs and can be easily divided into two periods; 1945 - 1965 and 1965 - 1998. In the first part, despite achieving impressive gains in health and education, the economy engaged in battling inflation and stagnation, while in the second part, it was engaged in consolidating the gains and strengthening the economic development of the country but at the expense of increasing economic disparities between haves and have-nots (Sudari, 2017; Kompas, 2018; Britannica, 2021; Tjoe, 2018). By buying more than it sells, by importing more than it exports, a nation endangers its balance of payments and, thus, its currency (Stalin, 1954). In 2020, Indonesia maintained a trade deficit with several key trading partners, including China, Australia, and Thailand. The biggest trade deficit was 5.32 billion dollars, followed by 1.5 trillion US dollars from Thailand, and 874 million US dollars in January-June 2020 from Australia (Fauzan, 2020). The trade deficit is problematic because it is only financed by capital flows (from trade-surplus countries), and its sudden cessation of capital flows creates instability at the national level and internationally (Yilmazkuday, 2021). The bilateral trade deficit does not need to be so concerned by a country with a bilateral trading deficit, but the bilateral trade deficit takes on significant importance, particularly in cases of chronic multilateral trade deficits. Then, it becomes necessary to identify countries with large commercial deficits in a country-specific analysis of trade to mitigate the trade deficit problem with such countries to reduce the deficit problem (Basu \& Datta, 2007). Table 1 summarizes important literature on Indonesia-China trade and economic relationships.

Sutrisno (2014) explains the issue of how to eliminate trade deficit in the trade balance. Trade deficits in the trade balance can be overcome by merging monetary and fiscal policies. One way to minimize the current account deficit (CAD) is to increase exports while decreasing imports, resulting in a trade balance surplus that can then be used to reduce the CAD. This study examined oil and gas exports and imports, as well as non-oil and gas imports. Several reasons contributed to the rise in the trade deficit on the import side, including an increase in energy demand, an increase in global oil prices, and an increase in the number of motorized vehicles. Meanwhile, on the export front, the average price of Indonesia's raw-goods export commodities has dropped. 
Table 1. The summary of selected literature on China-Indonesia economic relations

\begin{tabular}{|c|c|c|}
\hline Year & Description & Literature \\
\hline 1999 & $\begin{array}{l}\text { The study argued that with China's joining of WTO and other } \\
\text { regional trade agreements both China and its trading partners } \\
\text { including Indonesia are likely to benefit. }\end{array}$ & Atje and Gadhu (1999) \\
\hline 2007 & $\begin{array}{l}\text { The study compares China's and Indonesia's development strategies } \\
\text { and identify similar and distinctly different development patterns. }\end{array}$ & Hofman et al. (2007) \\
\hline 2011 & $\begin{array}{l}\text { The study argued that through in past the relationships between } \\
\text { China and Indonesia didn't go smooth however with time their } \\
\text { interests are converging and relationships are improving. The } \\
\text { strategic implications of these closer relations for Australia are } \\
\text { presented. }\end{array}$ & Nabbs-Keller (2011) \\
\hline 2012 & $\begin{array}{l}\text { The ups and downs of trade protectionism in Indonesia are studied } \\
\text { while highlighting Indonesia's ability to use regional and international } \\
\text { engagement to counterbalance rising protectionism. }\end{array}$ & Basri and Patunru (2012) \\
\hline 2014 & $\begin{array}{l}\text { The impact of Indonesia-China trade liberalization on the Indonesian } \\
\text { trade and the lives of Indonesian households has been study. }\end{array}$ & Sabaruddin et al. (2014) \\
\hline 2014 & $\begin{array}{l}\text { The study argued that through in past the relationships between } \\
\text { China and Indonesia were strained but post-Suharto Indonesia has } \\
\text { significantly improved its economic and political relations with China. } \\
\text { Consequently, not only new opportunities have arisen some } \\
\text { challenges and contradictions have also emerged. }\end{array}$ & Fukuoka \& Verico (2014) \\
\hline 2015 & $\begin{array}{l}\text { By building an econometric model to estimate the direct impacts of } \\
\text { the ASEAN-China Free Trade Agreement (ACFTA) on Indonesia } \\
\text { and China the study argued that though the agreement modestly } \\
\text { increased trade surplus for Indonesia overall, it contributed to to a } \\
\text { larger bilateral deficit with China. }\end{array}$ & Marks et al. (2015) \\
\hline 2015 & $\begin{array}{l}\text { The study reports resentment among Indonesian business sector } \\
\text { towards skewed trade relations between China and Indonesia } \\
\text { resulting from the ACFTA whom they believe to be responsible for } \\
\text { Indonesia's increasing trade deficit with China. The study discusses } \\
\text { the necessity of the ACFTA and why it needs continued } \\
\text { implementation. }\end{array}$ & Siwi (2015) \\
\hline 2016 & $\begin{array}{l}\text { The study reports the positive impact of ACFTA on Indonesia's } \\
\text { production, investment, trade and national income growth whereas } \\
\text { the negative impact of the depreciation of Rupiah against the U.S. } \\
\text { dollar on Indonesia's production and trade performance } \\
\text { consequently causing the national income deficit. }\end{array}$ & Jamilah et al. (2016) \\
\hline 2019 & $\begin{array}{l}\text { The study argues that with the economic rise of China the unipolar } \\
\text { world is becoming multipolar, and the Belt and Road Initiative is } \\
\text { likely to consolidate the gains resulting from the multilateralism while } \\
\text { improving the relations between China and its trading partners like } \\
\text { Indonesia. }\end{array}$ & Putri and Ma'rif (2019) \\
\hline
\end{tabular}

Ginting (2014) examines the evolution of Indonesia's trade balance from 2006 to 2013 to determine what factors contributed to the country's trade deficit over that period. This journal identifies the factors causing the trade deficit. From 2006 to 2011, Indonesia's trade balance results consistently showed a trade surplus, indicating that the country's export value was still greater than its import value. However, Indonesia's trade balance started to show a trade deficit from late 2011 to April - June 2013. The trade balance shortfall in 2012 was caused by strong imports of Indonesian oil and gas exceeding exports. Furthermore, Indonesia's non-oil and gas imports continue to rise. Meanwhile, on the export front, the average price of Indonesia's export goods, which are raw materials, has dropped. According to this journal, the relationship between domestic demand and the real exchange rate hurts the trade balance in Indonesia in the short term. When domestic demand increases, so do imports. Unlike the exchange rate, where it is understood that each Rupiah depreciates, the trade surplus rises. This event occurs because the low level will boost the export competitiveness of Indonesian goods due to the low price. On the other hand, foreign income considerations have a favorable relationship with Indonesia's trade balance. The greater 


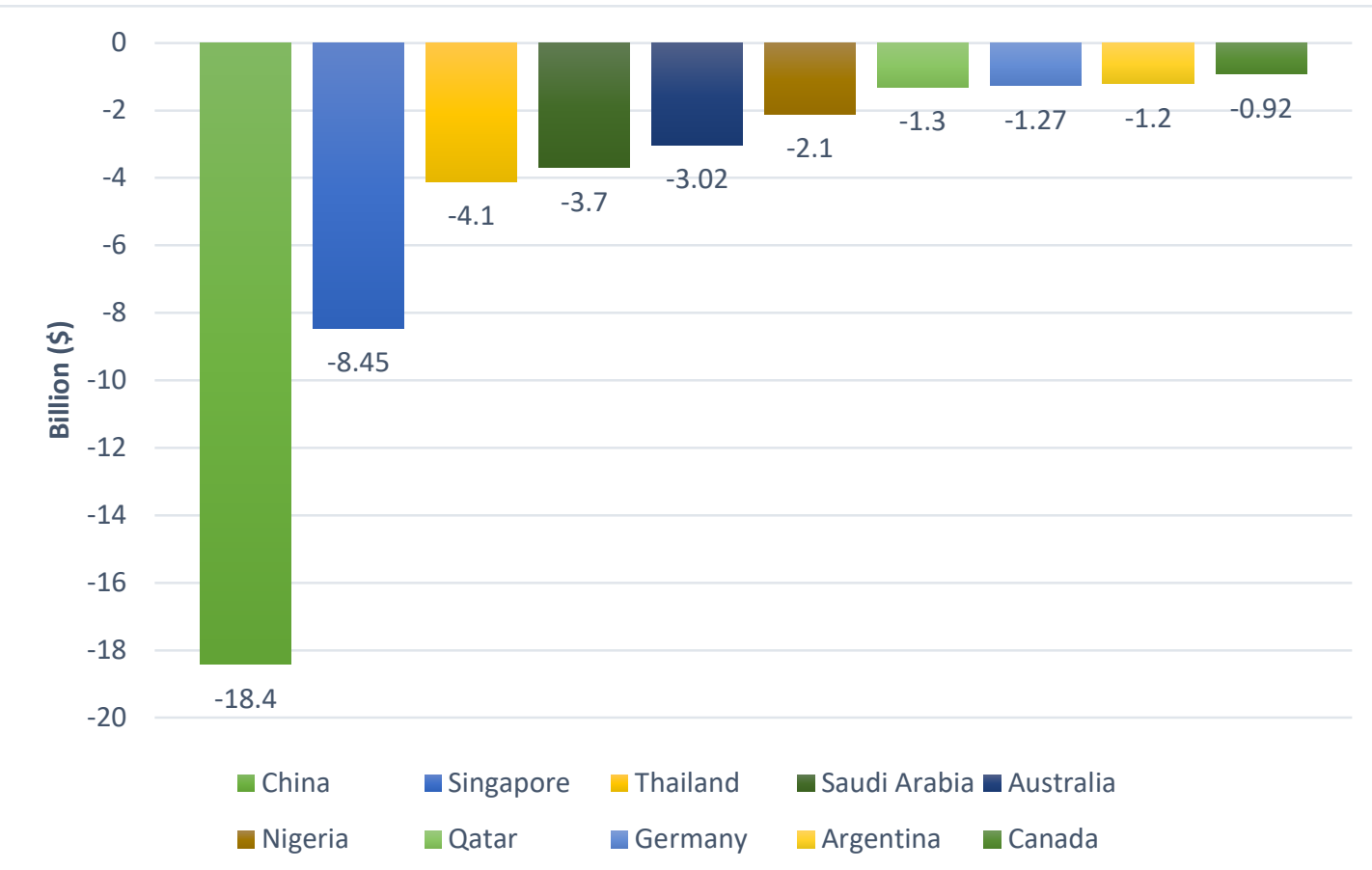

Figure 1. Top 10 countries with which Indonesia faces largest trade deficit (Data: WITS, 2018)

the other countries' international profits or GDP, the greater Indonesia's exports. Ginting (2014) concluded that the key cause of the trade imbalance in Indonesia's trade balance during that period was the strong imports relative to exports.

Indonesia traded with 210 countries from around the world and with 130 of them, it experienced a surplus, and with the remaining 80 it recorded a deficit (WITS, 2018). The top 10 countries that Indonesia had the largest trade deficit with, in 2018, are shown in Figure 1.

Indonesia has the most significant trade deficit with China at $\$ 18.4$ billion, followed by Singapore ( $\$ 8.45$ billion), Thailand ( $\$ 4.1$ billion), Saudi Arabia ( $\$ 3.7$ billion), Australia ( $\$ 3.02$ billion), Nigeria ( $\$ 2.1$ billion), Qatar ( $\$ 1.3$ billion), Germany ( $\$ 1.27$ billion), Argentina ( $\$ 1.2$ billion), and Canada ( $\$ 0.92$ billion). China is an important trading partner as well as Indonesia's largest trading partner, controlling $24.13 \%$ of Indonesia's market share in import partners and $15.05 \%$ in export partners (WITS, 2018).

\subsection{Trade deficit and its causes}

Trade deficits occur when a country's spending on consumption and investment exceeds the value of the goods and services produced (Mankiw, 2018). In this case, Indonesia is spending more than it can earn, which results in a deficit in the balance of trade (BoT). Indonesia's trade balance deficit is influenced by internal and external factors (Nabila, 2017). Internal factors include lack of infrastructure and weakening of Rupiah (Indonesian currency), while external factors include ASEAN-China Free Trade Agreement and the U.S.-China trade conflict.

2.2.1 Lack of infrastructure: Infrastructure is one aspect of the trade balance deficit. Lack of public infrastructure means lacking highways, public transit, clean water, bridges, airports, harbors, reservoirs, electricity, flood control, etc. (Kompas, 2013). Lack of infrastructure can affect the trade deficit. For instance, the use of fuel, creation of infrastructure needs substantial financing. The allocation of infrastructure funds is around Rp 201 trillion in the state budget for 2013. Infrastructure subsidies spent are less than the energy subsidies spent, which is estimated at Rp 274 trillion of Rp 1683 trillion of the total government spending (Tri Haryanto, 2013). Increasing fuel usage and decreasing oil production have further increased imports of petroleum products, which makes exports of petroleum and gas no longer cover them (Mangeswuri, 2014). In the meantime, the gasoline subsidies are partly financed by new government debt. Many residents enjoy subsidized 
gasoline, but a lack of public transit makes many people purchase cars. Oil and gas exports totaled only USD 34 billion during January-November 2012, while imports of petroleum and gas amounted to USD 39 billion. The deficit was almost US $\$ 5$ billion. The greater the fuel subsidy, the greater the shortfall of the government's budget. This is to the detriment of citizens' access to better health services and infrastructure. Funds have also been reduced to develop technical advances and enhance defense and protection.

2.2.2 Weakening of Rupiah: A significant part of the trade balance deficit is the Rupiah's exchange rate (Ningsih, 2019). Weakening the dollar exchange rate would undoubtedly harm the Indonesian economy and affect rising rates, which use the dollar as a tool for transactions (Diana \& Dewi, 2019). Under the weakening of the exchange rate Rupiah, the price of imported items would increase fast. The decline in the rupiah exchange rate represents a decline in the rupiah currency demand society, either due to the decreasing position of the national economy as a vehicle for international payments or to the rising demand for foreign currency. The effect is that the cost of importing raw materials increases.

The exchange rate varies on a free market, depending on many factors that affect foreign exchange supply and demand (Chomas et al., 2014). This exchange is essential for outgoing payment transactions across countries (imports). As the level of growth in income (relative to other countries) increases, more demand for foreign currency is maximized. Foreign exchange rates begin to rise, and currency prices themselves are falling.

2.2.3 ASEAN-China Free Trade Agreement. In 2010, Indonesia was one of the 6 ASEAN countries that decided to sign a cooperation agreement with China called the ASEAN-China Free Trade Agreement (ACFTA). It aimed to either reduce or remove trade barriers of goods, increase access to market services for both tariff and non-tariff products, control investment policy and provision, thus improving economic cooperation between ASEAN countries and China (Sari \& Suhadak, 2017). This agreement led to an increase in trade volume in both the import and export sectors between Indonesia and China. However, over time, the trade balance between Indonesia and China became asymmetrical where Indonesia focused on exporting products such as mining, oil, and gas (natural resources) while China exported manufactured products such as low priced electronics, machinery, and transportation-related goods, turning Indonesian-made goods inferior to those made in China (Muslihati, 2010). The huge price difference between imported products from China and domestically made products naturally makes consumers prefer imported goods from China over local products. This made local producers unable to compete and unbalanced Indonesia's trade balance.

2.2.4 The U.S.-China trade conflict. The high tension between China and the United States which began in July 2018, affected almost many other economies, including Indonesia, even though Indonesia was not directly involved in the trade war. Both China and the U.S. are Indonesia's main trading partners. The trade war between China and the U.S. left a negative impact on Indonesia, namely the second-round effect, a situation in which China and the U.S. reduced imports of raw materials from Indonesia due to an economic slowdown resulting from high tensions (Wangke, 2020). The effect can be shown in Table 2 , where the demand for oil and gas that was exported to China declined dramatically in 2019 from $\$ 2.72$ Billion to $\$ 2.06$ Billion. The decline in commodities' demand led to a reduction in the commodity prices as well, especially in the primary commodity that Indonesia exports, such as kernel oil, palm oil, and coal that experienced a contraction of $39.53 \%,-16.90 \%$, and $-7.41 \%$ (Iqbal et al., 2020).

Table 2. Indonesian data on oil and gas and non-oil and gas exports (Data: KPRI, 2021)

\begin{tabular}{|c|c|c|c|c|c|}
\hline Export & $\mathbf{2 0 1 6}$ & $\mathbf{2 0 1 7}$ & $\mathbf{2 0 1 8}$ & $\mathbf{2 0 1 9}$ & $\mathbf{2 0 2 0}$ \\
\hline Oil and gas & 1.67 & 1.73 & 2.72 & 2.06 & 1.84 \\
\hline Non-Oil and gas & 15.1 & 21.3 & 24.4 & 25.8 & 29.9 \\
\hline
\end{tabular}




\section{Research Methodology}

\subsection{Data collection}

The Indonesian import and export data concerning China from 2011 to 2020 was obtained from TE (2020) and KPRI (2021). The Trade Deficit (TD) and Trade Surplus (TS) were calculated from the formula of Balance of Trade (BoT), the difference between exports (E) and imports (I), as given below,

$$
B o T=\left\{\begin{array}{l}
T S ; E-I>0 \\
T D ; E-I<0
\end{array}\right.
$$

The future balance of trade was estimated through the same formula but instead of using actual data, the data simulated through the most accurate forecasting model was used.

\subsection{Grey forecasting model}

Deng (1982) proposed the Grey System Theory. The theory helps handle problems containing objective uncertainty (Javed \& Cudjoe, 2021) without requiring a large sample size with a specific probability distribution (Mahmoudi et al., 2021). Grey forecasting theory is an important offshoot of the Grey System Theory. Ma et al. (2019) and Javed et al. (2020a) applied grey forecasting in the tourism sector. Quartey-Papafio et al. (2020) and Zeng et al. (2020) used it for forecasting cocoa production and grain production, respectively. Javed and Liu (2018) and Ikram et al. (2019) used it to predict the number of research publications and ISO certifications of selected countries, respectively. Wu et al. (2020) and Xie et al. (2021) used it to predict $\mathrm{CO}_{2}$ emissions. Thus, with time the grey forecasting modeling is only becoming popular and seeing a large number of applications.

Even Grey Model EGM $(1,1)$ is an important model of the grey forecasting theory (Liu et al., 2017). EGM $(1,1, \alpha, \theta)$ is an optimized form of the EGM $(1,1)$, and is the grey model with a differential equation of first order containing a single variable and a weighted background value that contains a conformable fractional accumulation. It was proposed by Javed et al. (2020b), and the steps to calculate EGM $(1,1, \alpha, \theta)$, are reproduced below.

Let the actual data sequence be

$$
X^{(0)}=\left(x^{(0)}(1), x^{(0)}(2), \ldots x^{(0)}(n)\right)
$$

And the compatibility series of accumulated fractional data is

$$
X^{(\alpha)}=\left(x^{(\alpha)}(1), x^{(\alpha)}(2), \ldots x^{(\alpha)}(n)\right), \alpha \in(0,1], k=1,2, \ldots, n
$$

where, $x^{(\alpha)}(k)=\sum_{i=1}^{k}\left(\frac{x^{(0)}(i)}{i^{1-\alpha}}\right)$.

The approximate regressive equation is stated as

$$
\hat{x}^{(0)}(k)=k^{1-\alpha}\left(\hat{x}^{(\alpha)}(k)-\hat{x}^{(\alpha)}(k-1)\right)
$$

The time response function is

$$
\hat{x}^{(0)}(k)=k^{1-\alpha}\left(1-e^{a}\right)\left(x^{(0)}(1)-\frac{b}{a}\right) e^{-a(k-1)}
$$

EGM $(1,1, \alpha, \theta)$ has the advantage of being able to change the parameters of $\alpha$ and $\theta$ with data variance. Data noise may have various shapes. Contrary to the conventional model EGM $(1,1)$, the two parameter EGM model $(1,1, \alpha, \theta)$ is dynamic and changes the values of its parameters as noise in data varies, thus generating relatively more precise forecasts.

In the current study, Even Grey Model EGM $(1,1, \alpha, \theta)$ was used for forecasting Indonesian exports to China and Chinese imports to Indonesia. For comparative analysis, Linear Regression (LR), Exponential Regression (ER), and Exponential Triple Smoothing (ETS) methods were used. 
The model EGM $(1,1, \alpha, \theta)$ was built in MS Excel. For running LR, ER, and ETS, the built-in functions of MS Excel were used.

\subsection{Forecast error measurement}

The current study will use five metrics (Ofosu-Adarkwa et al., 2020) for the measurement of forecast error. These are Mean Absolute Error (MAE), Root Mean Square Error (RMSE), Normalized RMSE (NRMSE), Mean Absolute Percentage Error (MAPE), and Normalized MAPE (NMAPE), respectively given by

$$
\begin{aligned}
M A E & =\frac{1}{n}=\sum_{k=1}^{n}|x(k)-\hat{x}(k)| \\
R M S E & =\sqrt{\frac{1}{n} \sum_{k=1}^{n}(x(k)-\hat{x}(k))^{2}} \\
N R M S E & =\frac{\sqrt{\sum_{k=1}^{n}(x(k)-\hat{x}(k))^{2}}}{\sqrt{\sum_{k=1}^{n}(x(k))^{2}}} \\
\operatorname{MAPE}(\%) & =\frac{1}{n} \times \sum_{k=1}^{n}\left|\frac{x(k)-\hat{x}(k)}{x(k)}\right| \times 100 \\
\operatorname{NMAPE}(\%) & =\frac{1}{n} \times \sum_{k=1}^{n}\left|\frac{x(k)-\hat{x}(k)}{n} \sum_{k=1}^{n} x(k)\right| \times 100
\end{aligned}
$$

where, $x(k)$ represent actual data and $\hat{x}(k)$ represent simulated data.

\section{Results and discussion}

\subsection{Analysis of Trade between Indonesia and China}

As part of the ASEAN-China Free Trade Area (ACFTA), the flow of goods between China and Indonesia can move freely almost without a barrier, so the total trade between the two sites has significantly increased to a higher level. China is Indonesia's largest trading partner with a share of $15.05 \%$. The most imported products by Indonesia are non-oil and gas products such as electronics (HS 85) and machine goods (HS 84), while on the other hand, Indonesia exports oil and gas products such as mineral fuels, petroleum, distillation products (HS 27) and animal, vegetable fats and oils, cleavage products (HS 03) (Adharsyah, 2019).

In 2018, products imported to Indonesia accounted for the largest quantity worth $\$ 45.53$ Billion while the largest amount of products exported to China was in 2020 , worth $\$ 31.77$ Billion, as shown in Figure 2 and Table 3. 


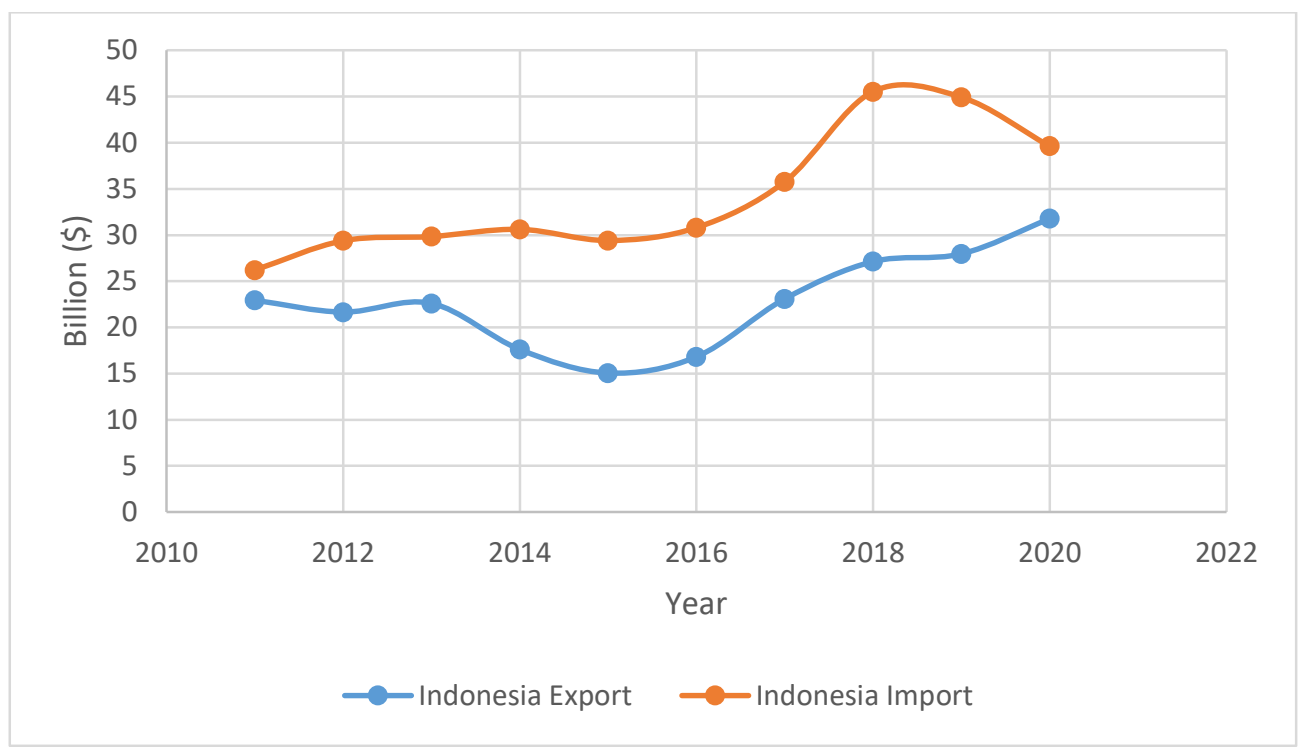

Figure 2. Total import and export between Indonesia and China (2011-2020)

Table 3. Historic data on Indonesian balance of trade (\$ billion) with China

\begin{tabular}{|c|c|c|c|}
\hline Year & Indonesian Exports to China & Indonesian Imports from China & Balance of Trade \\
\hline 2011 & 22.94 & 26.21 & -3.27 \\
\hline 2012 & 21.65 & 29.38 & -7.73 \\
\hline 2013 & 22.6 & 29.84 & -7.24 \\
\hline 2014 & 17.6 & 30.62 & -13.02 \\
\hline 2015 & 15.04 & 29.41 & -14.37 \\
\hline 2016 & 16.79 & 30.8 & -14.01 \\
\hline 2017 & 23.08 & 35.76 & -12.68 \\
\hline 2018 & 27.13 & 45.53 & -18.4 \\
\hline 2019 & 27.96 & 44.93 & -16.97 \\
\hline 2020 & 31.77 & 39.63 & -7.86 \\
\hline
\end{tabular}

\subsection{Calculating trade deficit between Indonesia and China}

To determine whether a country has a trade surplus (TS) or trade deficit (TD), we can calculate the Balance of Trade. Balance of Trade (BoT) is the difference between a country's exports (E) and imports (I). Table 3 highlights the BoT between Indonesia and China.

Since joining the ASEAN-China Free Trade Area (ACFTA) in 2010, Indonesia has never printed a trade surplus with China. The gap between imports and exports between China and Indonesia is also getting wider every year, as Chinese products satisfy consumers' needs in Indonesia with better quality and competitive prices (Rakhma, 2017). In 2020, due to the COVID-19 outbreak in China, the number of imported products from China dropped to $\$ 39.63$ Billion or $11.8 \%$. With the declining imports from China, Indonesia narrowed the trade deficit gap with China. However, this gain came at a cost borne by the industries and people affected by the pandemic.

\subsection{Forecasting trade deficit between Indonesia and China}

In this study research, the forecasts of Indonesia's current account deficit were made from 2021 until 2025. In this forecast, we use export, import, and balance of trade data from 2011 until 2019. The year 2020 was ignored because of the impact of the COVID-19. We use four forecasting methods; Even Grey Forecasting Model EGM $(1,1, \alpha, \theta)$, linear regression, error, trend, seasonal (ETS), and exponential regression. The forecasts are shown in Table 4. The results revealed that the trade deficit between Indonesia and China would likely grow in the next five years. Indonesia's import and export trends are shown in Figures 3 and 4, respectively. Using the forecast data, the balance of trade was estimated, and the results are shown in Figure 5, where the role of the COVID- 
Table 4. Forecasting Indonesia's trade balance ( $\$$ billion)

\begin{tabular}{|c|c|c|c|c|c|c|c|c|c|c|c|c|c|c|c|}
\hline \multirow[b]{2}{*}{ Year } & \multicolumn{3}{|c|}{ Actual } & \multicolumn{3}{|c|}{$\operatorname{EGM}(1,1, a, \theta)$} & \multicolumn{3}{|c|}{ Linear Regression } & \multicolumn{3}{|c|}{ ETS } & \multicolumn{3}{|c|}{ Exp. Regression } \\
\hline & $\mathbf{E}$ & I & BoT & $\mathbf{E}$ & I & BoT & $\mathbf{E}$ & I & BoT & $\mathbf{E}$ & I & BoT & $\mathbf{E}$ & I & BoT \\
\hline 2011 & 22.9 & 26.2 & -3.3 & 22.9 & 26.2 & -3.27 & 19.2 & 24.6 & -5.4 & 23.07 & 27.1 & -4.0 & 20.4 & 23.6 & -3.2 \\
\hline 2012 & 21.7 & 29.4 & -7.7 & 17.1 & 26.3 & -7.73 & 19.8 & 26.8 & -7.0 & 23.68 & 29.3 & -5.7 & 20.9 & 25.1 & -4.2 \\
\hline 2013 & 22.6 & 29.8 & -7.2 & 18.2 & 28.4 & -7.24 & 20.4 & 29.1 & -8.7 & 24.29 & 31.6 & -7.3 & 21.4 & 26.8 & -5.4 \\
\hline 2014 & 17.6 & 30.6 & -13.0 & 19.3 & 30.6 & -13.02 & 21.0 & 31.4 & -10.3 & 24.90 & 33.9 & -8.9 & 22.0 & 28.6 & -6.6 \\
\hline 2015 & 15.0 & 29.4 & -14.4 & 20.5 & 33.0 & -14.37 & 21.6 & 33.6 & -12.0 & 25.52 & 36.1 & -10.6 & 22.5 & 30.5 & -7.9 \\
\hline 2016 & 16.8 & 30.8 & -14.0 & 21.8 & 35.6 & -14.01 & 22.3 & 35.9 & -13.6 & 26.13 & 38.4 & -12.2 & 23.1 & 32.5 & -9.4 \\
\hline 2017 & 23.1 & 35.8 & -12.7 & 23.1 & 38.4 & -12.68 & 22.9 & 38.1 & -15.3 & 26.74 & 40.6 & -13.9 & 23.6 & 34.6 & -11.0 \\
\hline 2018 & 27.1 & 45.5 & -18.4 & 24.5 & 41.4 & -18.4 & 23.5 & 40.4 & -16.9 & 27.35 & 42.9 & -15.5 & 24.2 & 36.9 & -12.7 \\
\hline 2019 & 28.0 & 44.9 & -17.0 & 25.9 & 44.6 & -16.97 & 24.1 & 42.6 & -18.5 & 27.96 & 45.1 & -17.2 & 24.8 & 39.3 & -14.5 \\
\hline 2020 & 31.8 & 39.6 & -7.86 & 27.5 & 48.1 & -20.6 & 24.7 & 44.9 & -20.2 & 28.57 & 47.4 & -18.8 & 25.4 & 41.9 & -16.5 \\
\hline 2021 & & & & 29.1 & 51.8 & -22.7 & 25.3 & 47.1 & -21.8 & 29.18 & 49.7 & -20.5 & 26.1 & 44.7 & -18.7 \\
\hline 2022 & & & & 30.8 & 55.9 & -25.0 & 25.9 & 49.4 & -23.5 & 29.79 & 51.9 & -22.1 & 26.7 & 47.7 & -21.0 \\
\hline 2023 & & & & 32.6 & 60.2 & -27.6 & 26.5 & 51.7 & -25.1 & 30.40 & 54.2 & -23.8 & 27.4 & 50.8 & -23.5 \\
\hline 2024 & & & & 34.6 & 64.9 & -30.3 & 27.1 & 53.9 & -26.8 & 31.02 & 56.4 & -25.4 & 28.0 & 54.2 & -26.1 \\
\hline 2025 & & & & 36.6 & 70.0 & -33.4 & 27.8 & 56.2 & -28.4 & 31.63 & 58.7 & -27.1 & 28.7 & 57.8 & -29.0 \\
\hline
\end{tabular}

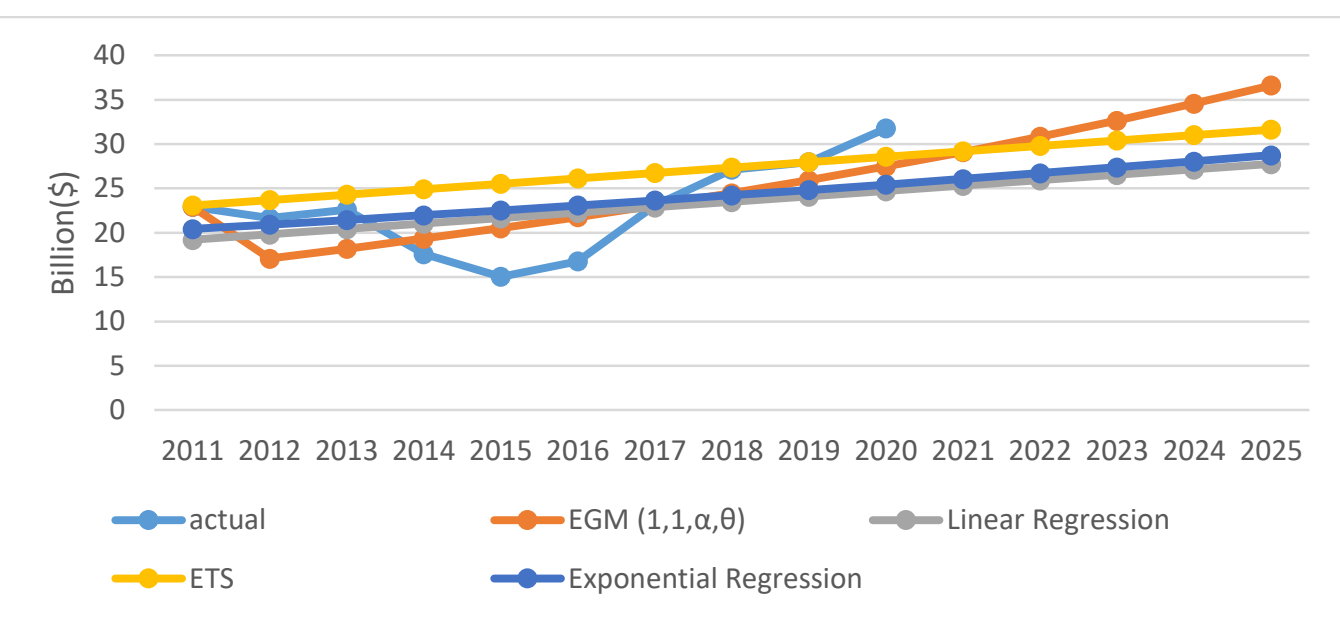

Figure 3. Forecast of Indonesia's export trend

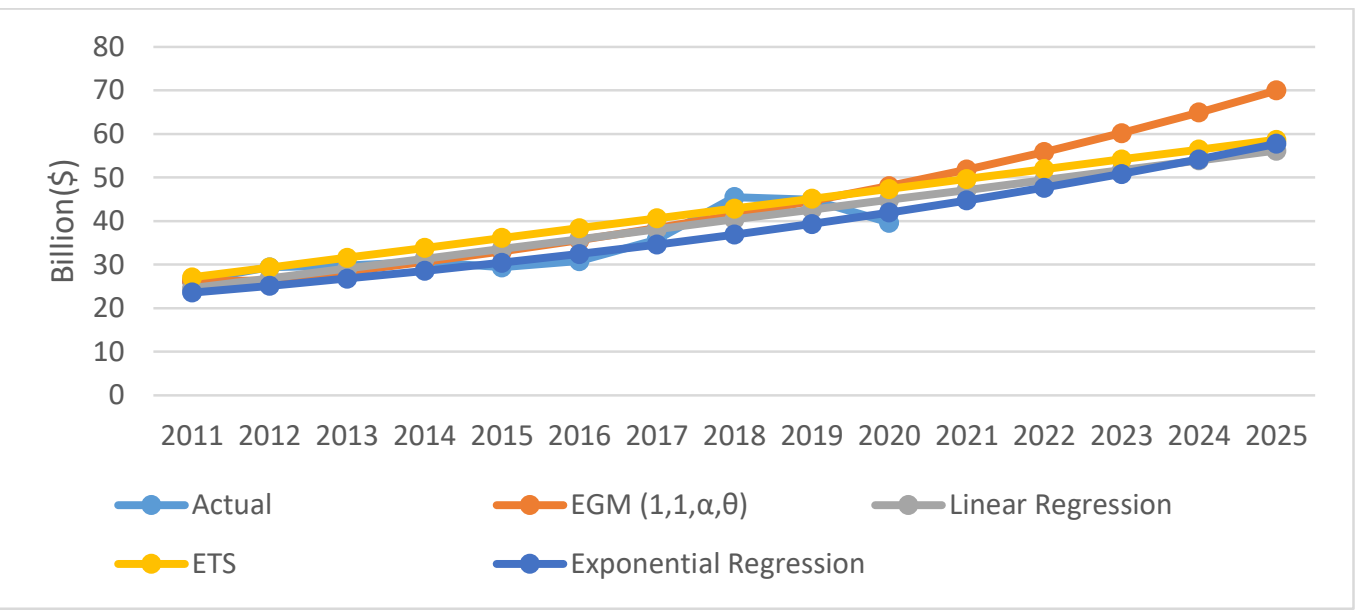

Figure 4. Forecast of Indonesia's import trend 


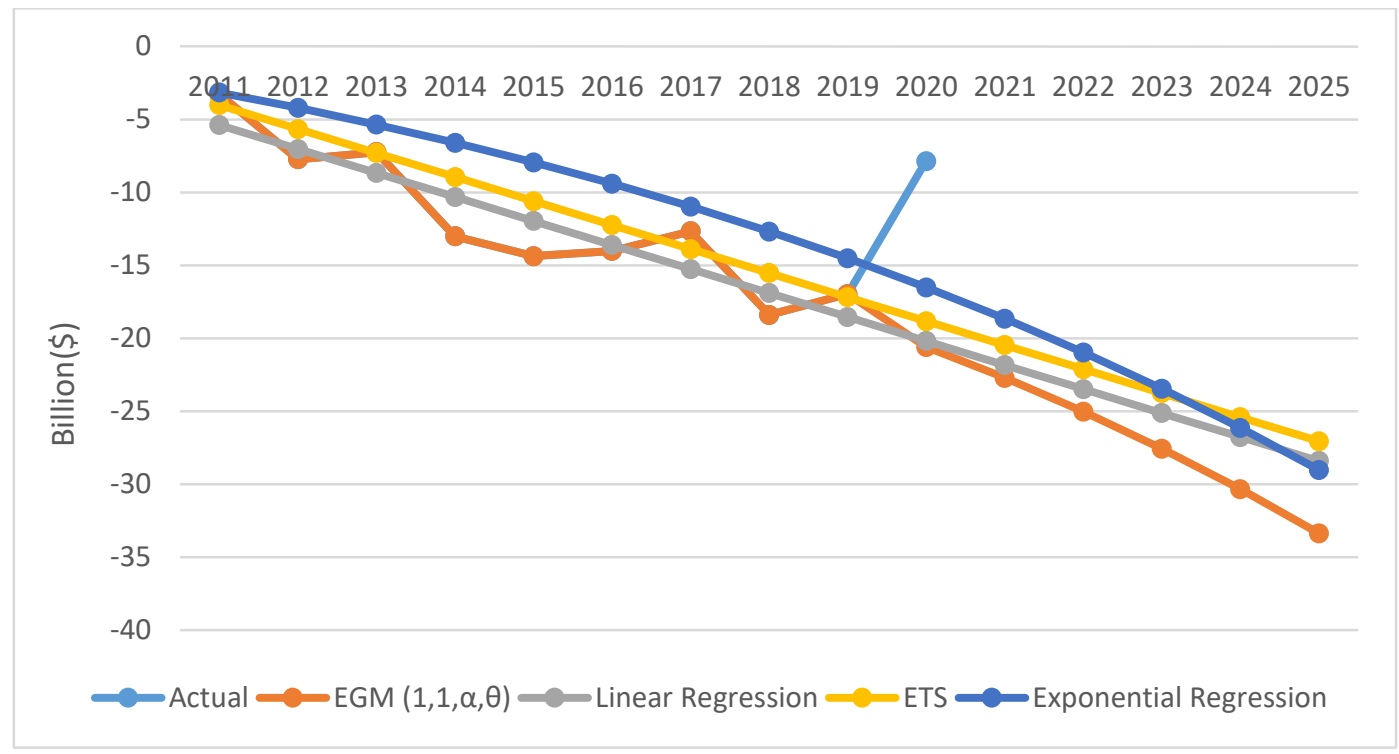

Figure 5. Estimates of Indonesia's Balance of Trade trend

Table 5. Forecast error measurement of the forecasting models

\begin{tabular}{|c|c|c|c|c|c|c|c|c|c|c|}
\hline \multirow{2}{*}{ Model } & \multicolumn{2}{|c|}{ MAE } & \multicolumn{2}{c|}{ RMSE } & \multicolumn{2}{c|}{ NRMSE } & \multicolumn{2}{c|}{ MAPE (\%) } & \multicolumn{2}{c|}{ NMAPE (\%) } \\
\cline { 2 - 12 } & Export & Import & Export & Import & Export & Import & Export & Import & Export & Import \\
\hline EGM (1,1,a,, ) & 3.2 & 2.5 & 3.7 & 3.0 & 0.17 & 0.09 & 16.7 & 7.5 & 14.93 & 7.43 \\
\hline Linear regression & 3.4 & 2.7 & 3.9 & 3.2 & 0.18 & 0.09 & 17.6 & 8.2 & 13.99 & 7.63 \\
\hline ETS & 3.9 & 3.1 & 5.5 & 4.0 & 0.25 & 0.12 & 22.3 & 9.7 & 17.82 & 9.22 \\
\hline Exp. Regression & 3.2 & 3.3 & 4.0 & 4.1 & 0.18 & 0.12 & 17.3 & 9.4 & 14.95 & 9.93 \\
\hline
\end{tabular}

19 in reducing the trade deficit is visible. The forecast errors are shown in Table 5. Based on the error analysis, it can be argued that from all forecasting models, the EGM $(1,1, \alpha, \theta)$ provided the most accurate picture of the trade deficit between Indonesia and China.

If one looks at Figure 5, one can see the impact of the COVID-19 on Indonesia's trade balance with China. If the COVID-19 outbreak wasn't a factor of influence, the current study predicts that Indonesia's trade deficit with China was likely to reach $-\$ 20.6$ Billion by 2020 (here negative sign shows deficit). Even though the COVID-19 pandemic may have reduced Indonesia's trade deficit with China for a year, it is not something to celebrate as the cause of this reduction is alarming. Further, the pandemic is temporary, and delays in fighting the COVID-19 may temporarily reduce Indonesia's trade deficit with China but would ultimately hurt Indonesia because the wheels of the national economy would become increasingly fragile with time, paving way for increasing unemployment and poverty, and making companies vulnerable to bankruptcy claims. Thus, there is a need to take serious lessons from the pandemic and its effects on the Indonesian economy.

\section{Conclusion and recommendations}

The trade deficit happens when a country's imports surpass exports. A small trade deficit is acceptable, but a large trade deficit can be a sign of worry. Since 2008, Indonesia never had a trade surplus with China. The trade data between Indonesia and China in the last ten years provide us information on several causes of the trade deficit between Indonesia and China. These factors, both internal and external, are highlighted in the current study. Using a grey forecasting model, the study forecasts Indonesia's trade deficit with China to reach -\$33.4 Billion in 2025. As compared to three statistical forecasting models, the grey forecasting model showed superior performance.

The widening gap between imports and exports is a sign of worry. Indonesian policymakers need to revisit their trade relationship with China by fully grasping the strengths and limitations of the nation and its industries. It is suggested that the Indonesian government adopt a mixed policy 
to prevent the worsening trade deficit between Indonesia and China, a mixed policy consisting of fiscal and monetary policies. It should include granting tax breaks for imports of raw goods, improving agricultural products, increasing biodiesel made from palm oil, and supporting the provision of land for the agricultural sector. The monetary policy that provides incentives to domestic exporters should be enforced, and Bank Indonesia must maintain interest rates and the exchange rate of the Indonesian currency to support the policies.

The study has five recommendations for the Indonesian policymakers: (a) Indonesia should negotiate with China under ACFTA's circumstances in deregulation of tariff restrictions and import quotas to prevent imbalance and industrialization. (b) The government needs to develop bilateral and multilateral ways to introduce the local products with the aid of international shows. The products to be displayed are authentic products such as ground coffee, prawn crackers, instant noodles, and coffee beans. (c) Increasing the use of biodiesel made from palm oil (Indonesia is the largest exporter of palm oil, with an export rate of 50\%). By slowly replacing diesel with biodiesel made from palm oil, Indonesia can reduce diesel imports because of the reduction in the trade deficit. Following in the footsteps of China, a shift toward electric vehicles is another option. (d) The government should encourage the production of food items like garlic, onions, sugar, potatoes, and chilies, which are usually imported products from China. Based on the provision of land will lead to food self-sufficient, which means we can reduce the trade deficit. (e) Investments in tertiary industries and the technology-driven industries of the future should be improved. Also, lessons can be learned from China's way of trading with other nations.

By reducing the trade deficit of Indonesia with China, the COVID-19 has highlighted another deficit - humanity's deficit with nature, where we extract more resources from nature than we invest in nature. This deficit rarely finds its mention in the rooms of economic policymakers and corporate boardrooms except for some talk about it in the media and the Sustainability Reports. The study concludes with some important questions for the readers, in general, and the policymakers, in particular. Also, in the future, efforts should be made to improve the trade forecasting models. A grey forecasting model may also be proposed, especially for trade deficit predictions.

\section{References}

Adam, L., \& Negara, S. D. (2010). ASEAN-CHINA Free Trade Sgreement: Challenges and Opportunities for Indonesia [ASEAN-CHINA Free Trade Agreement: Tantangan dan Peluang bagi Indonesia]. Masyarakat Indonesia, 36(1), 1-24. http://jmi.ipsk.lipi.go.id/index.php/jmiipsk/article/view/633

Adharsyah, T. (2019). Here are 10 imported goods from China that flooded the Republic of Indonesia [ni Dia 10 Barang Impor Dari China yang Banjiri RI. Tech]. CNBC Indonesia. https://www.cnbcindonesia.com/tech/20190710153138-37-83969/ini-dia-10-barang-impor-darichina-yang-banjiri-ri

Atje, R., \& Gaduh, A. B. (1999). Indonesia-China Economic Relations : An Indonesian Perspective. CSIS Economics Working Paper Series WPE052, Centre for Strategic and International Studies, Jakarta, Indonesia.

Basri, M. C., \& Patunru, A. A. (2012). How to keep trade policy open: The case of Indonesia. Bulletin of Indonesian Economic Studies, 48(2), 191-208. https:/ / doi.org/10.1080/00074918.2012.694154

Basu, S., \& Datta, D. (2007). India-Bangladesh trade deficit and misaligned bilateral exchange rate: Can Bangladesh draw lessons from Indonesia?. Journal of the Asia Pacific Economy, 12(1), 76-102. https://doi.org/10.1080/13547860601083751

Britannica. (2021). Sukarno. Encyclopædia Britannica. https://www.britannica.com/biography/Sukarno

Chomas, S. F., Romli, R. A., Nurzaman, N., \& Hakim, L. (2014). The impact of fuel imports on the exchange rate [dampak impor bbm terhadap nilai tukar]. Economics Development Analysis Journal, 3(2), 412-419. https://journal.unnes.ac.id/sju/index.php/edaj/article/download/3850/3480

Diana, I. K. A., \& Dewi, N. P. M. (2019). Analysis of the Factor Affecting the Rupiah Exchange Rate against the United States Dollar in Indonesia [Analisis Faktor-Faktor Yang Mempengaruhi Nilai Tukar Rupiah Atas Dolar Amerika Serikat di Indonesia]. E-Jurnal EP Unud, 9(8), 1631-1661. https://ojs.unud.ac.id/index.php/eep/article/download/60977/36048 
Fauzan, R. (2020). Indonesia is still in deficit with these countries [Indonesia Masib Defisit dengan Negara-negara Ini].EkonomiBisnis.com. https://ekonomi.bisnis.com/read/20200715/12/1266426/indonesia-masihdefisit-dengan-negara-negara-ini

Fukuoka, Y., Verico, K. (2016). Indonesia-China Economic Relations in the Twenty-First Century: Opportunities and Challenges. In: Kim YC. (eds) Chinese Global Production Networks in ASEAN. Understanding China. Springer, Cham. https://doi.org/10.1007/978-3-319-24232-3_4

Ginting, A. M. (2014). The development of the trade balance and the factors that influence it [perkembangan neraca perdagangan dan faktor-faktor yang mempengaruhinya]. Buletin Ilmiah Litbang Perdagangan, 8(1), 51-72. https://doi.org/10.30908/bilp.v8i1.85

Ginting, A. M. (2017). Analysis of the Effect of Exports on Indonesia's Economic Growth [Analisis Pengaruh Ekspor Terhadap Pertumbuhan Ekonomi Indonesia]. Buletin Ilmiah Litbang Perdagangan, 11(1), 1-20. https://doi.org/10.30908/bilp.v11i1.185

Hofman, B., Zhao, M., \& Ishihara, Y. (2007). Asian development strategies: China and Indonesia compared. Bulletin of Indonesian Economic Studies, 43(2), 171-200. https:/ / doi.org/10.1080/00074910701408057

Ikram, M., Mahmoudi, A., Shah, S. Z. A., \& Mohsin, M. (2019). Forecasting number of ISO 14001 certifications of selected countries: application of even GM (1, 1), DGM, and NDGM models. Environmental Science and Pollution Research, 26(12), 12505-12521. https://doi.org/10.1007/s11356-01904534-2

IMND. (2019). (2019). Development of Commodity Prices in International Markets Perkembangan Harga Komoditas di Pasar Internasional]. Indonesian Ministry of National Development. https://www.bappenas.go.id/id/profil-bappenas/unit-kerja/deputi-bidang-ekonomi/direktoratperencanaan-makro/contents-direktorat-perencanaan-makro/perkembangan-harga-komoditas-dipasar-internasional/

Iqbal, M., Elianda, Y., Akbar, A., \& Nurhadiyanti. (2020). USA-China trade war: Economic impact on Indonesia. Journal of Public Affairs, September, e2543. https://doi.org/10.1002/pa.2543

Jamilah, Sinaga, B. M., Tambunan, M., \& Hakim, D. B. (2016). The Impact of Indonesia-China Trade Agreement on Indonesia Trade Performance. Global Journal of Interdisciplinary Social Sciences, 5(3), 8-19. https://www.longdom.org/articles/the-impact-of-indonesiachina-trade-agreement-on-indonesiatrade-performance.pdf

Javed, S. A., \& Cudjoe, D. (2021). A novel Grey Forecasting of Greenhouse Gas Emissions from four Industries of China and India. Sustainable Production and Consumption, 29, 777-790. https://doi.org/10.1016/j.spc.2021.11.017

Javed, S. A., \& Liu, S. (2018). Predicting the Research Output/Growth of Selected Countries: Application of Even GM (1, 1) and NDGM Models. Scientometrics, 115(1), 395-413. https://doi.org/10.1007/s11192-017-2586-5

Javed, S. A., Bo, Y., Tao, L., \& Dong, W. (2021). The 'Dual Circulation' Development Model of China: Background and Insights. Rajagiri Management Journal. https://doi.org/10.1108/RAMJ-03-2021-0016

Javed, S. A., Ikram, M., Tao, L., \& Liu, S. (2020a). Forecasting Key Indicators of China's Inbound and Outbound Tourism: Optimistic-Pessimistic Method. Grey Systems: Theory and Application, 11(2), 265287. https://doi.org/10.1108/GS-12-2019-0064

Javed, S. A., Zhu, B., \& Liu, S. (2020b). Forecast of biofuel production and consumption in top $\mathrm{CO}_{2}$ emitting countries using a novel grey model. Journal of Cleaner Production,276, 123997. https://doi.org/10.1016/j.jclepro.2020.123997

Kompas. (2013). Infrastructure and the Trade Balance [Infrastruktur dan Neraca Perdagangan] Halaman all KOMPAS.

https://properti.kompas.com/read/2013/01/31/02124316/infrastruktur.dan.neraca.perdagangan?

Kompas. (2018). Indonesia's Economic Growth Footprint from Time to Time [Jejak Pertumbuhan Ekonomi Indonesia dari Masa ke Masa]. KOMPAS. https://jeo.kompas.com/jejak-pertumbuhan-ekonomiindonesia-dari-masa-ke-masa

KPRI. (2021). Trade Balance with Trading Partners [Neraca Perdagangan Dengan Mitra Dagang] - Portal Statistik Perdagangan. Kementrian Perdagangan Republik Indonesia. https://statistik.kemendag.go.id/balance-oftrade-with-trade-partner-country

Liu, S., Yang, Y., \& Forrest, J. (2017). Grey Data Analysis - Methods, Models and Applications. Singapore: Springer.

Ma, X., Liu, Z., \& Wang, Y. (2019). Application of a novel nonlinear multivariate grey Bernoulli model to predict the tourist income of China. Journal of Computational and Applied Mathematics, 347, 84-94. https://doi.org/10.1016/j.cam.2018.07.044

Mahmoudi, A., Javed, S.A., \& Deng, X. (2021). Earned Duration Management under Uncertainty. Soft Computing. https://doi.org/10.1007/s00500-021-05782-6 
Mangeswuri, D. R. (2014). Trade Balance Fluctuations [Fluktuasi Neraca Perdagangan]. Info Singkat Ekonomi Dan Kebijakan Publik, 6(7), 13-16. https://berkas.dpr.go.id/

Mankiw, N. G. (2018). Surprising Truths About Trade Deficits. The New York Times.

Mankiw, N. G., \& Taylor, M. P. (2020). Economics (5 ${ }^{\text {th }}$ ed.). Cengage Learning/EMEA.

Marks, S. V. (2015). the ASEAN-China Free Trade Agreement: Political Economy in Indonesia. Bulletin of Indonesian Economic Studies, 51(2), 287-306. https://doi.org/10.1080/00074918.2015.1061917

Muslihati. (2010). Analysis of Indonesia's Trade After the Implementation of ACFTA (Comperative Study of Indonesia-China) [Analisis Perdagangan Indonesia Pasca Pemberlakuan ACFTA (Studi Komparatif Indonesia-China)]. Jurnal Ekonomi Pembangunan, 8(2), 383. https://doi.org/10.22219/jep.v8i2.3614

Nabbs-Keller, G. (2011). Growing Convergence, Greater Consequence: The Strategic Implications of Closer Indonesia-China Relations. Security Challenges, 7(3), 23-41. http://hdl.handle.net/10072/42305

Nabila, E. (2017). Factors of Indonesia's trade balance deficit with China (2012-2014) [Faktor-faktor defisit neraca perdagangan Indonesia dengan Tiongkok (2012-2014)]. Undergraduate Thesis. Universitas Katolik Parahyangan. http://repository.unpar.ac.id/handle/123456789/2263

Ningsih, L. (2019). What is the Trade Balance? [Apa Itu Neraca Perdagangan?]. Wartaekonomi. Retrieved from https://www.wartaekonomi.co.id/read223842/apa-itu-neraca-perdagangan

Ofosu-Adarkwa, J., Xie, N., \& Javed, S. A. (2020). Forecasting CO2 emissions of China's cement industry using a hybrid Verhulst-GM(1,N) model and emissions' technical conversion. Renewable and Sustainable Energy Reviews, 130, 109945. https://doi.org/10.1016/j.rser.2020.109945

Putri, S. Y., \& Ma'arif, D. (2019). Economic-Political Cooperation between Indonesia and China in the Implementation of the Belt and Road Initiative Program [Kerja Sama Ekonomi-Politik Indonesia dan Cina pada Implementasi Program Belt and Road Initiative]. Jurnal Kajian Lemhanas RI, 7(3), 53-66. https://jurnal.lemhannas.go.id/index.php/jkl/article/view/78

Quartey-Papafio, T. K., Javed, S.A. \& Liu, S. (2020). Forecasting cocoa production of six major producers through ARIMA and grey models. Grey Systems: Theory and Application, 11(3), 434-462. https://doi.org/10.1108/GS-04-2020-0050

Rakhma, D. S. S. (2017). Can Indonesia Stop Importing Goods from China? [Apakab Indonesia Bisa Stop Impor Barang dari China?] Kompas. https://ekonomi.kompas.com/read/2017/10/16/153000226/apakahindonesia-bisa-stop-impor-barang-dari-china-

Sabaruddin, S. S. (2016). The Impact of Trade Liberalization between Indonesia and China on Changes in Trade and Public Welfare in Indonesia: A Partial Equilibrium Approach (SMART Model) and Utilization of the 2008 Socio-Economic Balance System [Dampak Liberalisasi Perdagangan RI-China Terhadap Perubahan Perdagangan dan Kesejahteraan Masyarakat Indonesia: Sebuah Pendekatan Ekuilibrium Parsial (SMART Model) dan Pemanfaatan Sistem Neraca Sosial Ekonomi 2008]. Jurnal Ekonomi Dan Bisnis, 17(3), 33. https://doi.org/10.24914/jeb.v17i3.287

Salvatore, D. (2011). Introduction to International Economics (3 ${ }^{\text {rd }}$ Ed.). Wiley.

Sari, Y., \& Suhadak, S. (2017). The influence of the ASEAN-China Free Trade Agreement (ACFTA) on the export of Indonesian palm oil and natural rubber commodities to China (Study on the Trade Map for the 2006-2014 Period) [pengaruh ASEAN-China free trade agreement (ACFTA) terhadap ekspor komoditi kelapa sawit dan karet alam indonesia ke china (Studi pada Trade Map Periode Tahun 20062014)]. Jurnal Administrasi Bisnis 51 Universitas Brawijaya, 44(1), 54-61.

Siwi, A. P. (2015). Bilateral Free Trade: Indonesia-China Trade Relations within the Framework of the ACFTA [Bilateral Free Trade: Hubungan Perdagangan Indonesia-China dalam Kerangka ACFTA]. Hubungan Internasional, 1-17. http://journal.unair.ac.id/filerPDF/ARISA PERMATA SIWI070912091-JURNAL SKRIPSI.pdf

Stalin, J. V. (1953). Works (Vol. 7, pp. 265-403). Moscow: Foreign Languages Publishing House.

Sudari, E. K. (2017). Indonesia's Economic Transformation [Transformasi Perekonomian Indonesia]. Faculty of Economics and Business, Airlangga University. https:// feb.unair.ac.id/index.php/download/download-materiseminar.html?download=76:transformasi-perekonomian-indonesia $\% 0 \mathrm{~A} \% 0 \mathrm{~A}$

Sugiartiningsih. (2020). Analysis of Macro Factors Affecting Trade between Indonesia and China in Responding to the Free Market in 2020 [Analisis Faktor-Faktor Makro Yang Berpengaruh Terhadap Perdagangan Indonesia Dengan Cina Dalam Usaha Merespon Pasar Bebas Tahun 2020]. 1-10. https://repository.widyatama.ac.id/xmlui/bitstream/handle/123456789/4991/FP_36\%28sugiartini ngsih\%29.pdf

Sutrisno. (2019). Problems and Strategies to Overcome Indonesia's Trade Balance Deficit [Masalah dan Strategi Mengatasi Defisit Neraca Perdagangan Indonesia]. Journal of Indonesian Economy and Business, 21(3), 268-277. https://ejournal.borobudur.ac.id/index.php/1/article/view/605/580e 
TE. (2020). Indonesia Imports from China | 2000-2020 Data | 2021-2023 Forecast | Historical. Trading Economics. https:/ / tradingeconomics.com/indonesia/imports-from-china

Tjoe, Y. (2018, August 28). Economic growth for 20 years has only been enjoyed by the rich. How severe is inequality in Indonesia [Pertumbuhan ekonomi selama 20 tahun hanya dinikmati orang kaya. Seberapa parah ketimpangan di Indonesia?]. The Conversation. https://theconversation.com/pertumbuhanekonomi-selama-20-tahun-hanya-dinikmati-orang-kaya-seberapa-parah-ketimpangan-di-indonesia102107

Tri Haryanto, J. (2013). The Face of Energy Subsidies in the Future [Wajah Subsidi Energi di Masa Depan]. Indonesian Ministry of Finance. http://www.anggaran.kemenkeu.go.id/in/post/wajah-subsidienergi-di-masa-depan

Wangke, H. (2020). Implications of United States - China Trade War to Indonesia. International Journal of Business and Economics Research, 9(3), 151-159. https://doi.org/10.11648/j.ijber.20200903.18

WITS. (2018). World Integrated Trade Solution (WITS). https://wits.worldbank.org/

Wu, W., Ma, X., Zhang, Y., Li, W., \& Wang, Y. (2020). A novel conformable fractional non-homogeneous grey model for forecasting carbon dioxide emissions of BRICS countries. Science of The Total Environment, 707, 135447. https://doi.org/10.1016/j.scitotenv.2019.135447

Xie, W., Wu, W.-Z., Liu, C., Zhang, T., \& Dong, Z. (2021). Forecasting fuel combustion-related $\mathrm{CO}_{2}$ emissions by a novel continuous fractional nonlinear grey Bernoulli model with grey wolf optimizer. Environmental Science and Pollution Research, 28, 38128-38144. https://doi.org/10.1007/s11356-02112736-w

Yilmazkuday, H. (2021). Accounting for Trade Deficits. Working Papers 2107, Florida International University, Department of Economics.

Zeng, B., Li, H., \& Ma, X. (2020). A novel multi-variable grey forecasting model and its application in forecasting the grain production in China. Computers \& Industrial Engineering, 150, 106915. https://doi.org/10.1016/j.cie.2020.106915 